\title{
Formulation and Evaluation of Solid Lipid Nanoparticle Containing Silver Sulfadiazine for Second and Third Degree Burn Wounds and its Suitable Analytical Method Development and Validation
}

\author{
Vinayak Shivamurthi Mastiholimath ${ }^{1, *}$, Coutinho Tracy Whitney Valerie', Vinodkumar Shrishailappa \\ Mannur ${ }^{1}$, Panchaxari Mallappa Dandagi ${ }^{2}$, Anand Panchaxari Gadad ${ }^{2}$, Pukar Khanal ${ }^{3}$

\begin{abstract}
${ }^{1}$ Department of Pharmaceutical Quality Assurance, KLE College of Pharmacy-Belagavi, KLE Academy of Higher Education and Research (KAHER) Belagavi, Karnataka, INDIA.

${ }^{2}$ Department of Pharmaceutics, KLE College of Pharmacy-Belagavi, KLE Academy of Higher Education and Research (KAHER), Belagavi, Karnataka, INDIA.

${ }^{3}$ Department of Pharmacology and Toxicology, KLE College of Pharmacy-Belagavi, KLE Academy of Higher Education and Research (KAHER), Belagavi, Karnataka, INDIA.
\end{abstract}

\begin{abstract}
Aim: The main aim of this research work was to formulate, characterize and evaluate solid lipid nanoparticles containing Silver sulfadiazine. Materials and Methods: Solid lipid nanoparticles were prepared by hot homogenisation technique using Glycerol distearate, Tween 80 and Millipore water. These nanoparticles were then incorporated into a gel using Carbopol and trietnanolamine Optimised formulation was chosen according to its particle size, as it was for topical use. Various different evaluation parameters like viscosity, spreadability, drug content, $\mathrm{pH}$ were carried out. Results and Discussion: The in vitro drug release study was performed for $12 \mathrm{hrs}$ and the optimised formulation (F4) gave best results. Antimicrobial studies all four formulation carried out and F4 gave better results than the other formulations. The gel drug content was analysed by HPTLC. All the physical parameters were in acceptable limit of pharmacopoeial specifications. A simple, precise, accurate and high performance thin layer chromatographic method was developed for estimation of Silver Sulfadiazine (SSD) which was prepared as a dosage form. The separation was performed out on Merck HPTLC aluminium plates of silica gel $\mathrm{G}_{60} \mathrm{~F}_{254},(20 \times 10 \mathrm{~cm})$ with $250 \mu \mathrm{m}$ thickness using n-propanol:25\% ammonia $(7: 3 \mathrm{v} / \mathrm{v})$ as mobile phase the wavelength was found to $266 \mathrm{~nm}$ the drug resolved satisfactorily with $R_{f} 0.451$. The calibration plot gave good linear relationship with $R^{2}$ value of 0.9988 in the concentration range of 0.2 to $1.2 \mu \mathrm{g} / \mathrm{ml}$ for SSD.

Key words: Analytical method, Burn wounds, HPTLC, Silver sulfadiazine, Solid Lipid Nanoparticles.
\end{abstract}

\section{INTRODUCTION}

Nanotechnology can be described as design characterisation, production and application of structures, devices and systems by controlling shape and its size at a nanometer scale. The colloidal particles should be within its range and the range should be within 10 to $1000 \mathrm{~nm}$ and these particles are known as nanoparticles. Solid lipid nanoparticles consist of drug trapped inside a lipid core and a surfactant as the outer shell which ultimately makes it a better option for to polymeric systems with respect to low toxicity. ${ }^{1-3}$

\section{Silver Sulfadiazine}

Silver sulfadiazine is a drug which is a combination of silver and sulfadiazine. Silver
Submission Date: 21-05-2019; Revision Date: 04-09-2019; Accepted Date: 06-11-2019

DOI: 10.5530/ijper.54.1.5 Correspondence: Dr. Vinodkumar Shrishaila Mastiholimath, Department of Pharmaceutical Quality Assurance, KLE College of Pharmacy, KAHER, Belagavi-590010, Karnataka, INDIA. Phone: +91-0831-2471399 E-mail: mastiholimath@ rediffmail.com

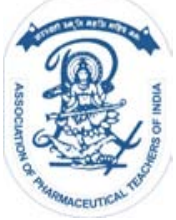

www.ijper.org 
sulfadiazine is a polymer in which each silver ion is tetracordinated and they are enclosed by 3 different deprotonated sulfa molecule and each individual molecule binds to 3 different silver ions. ${ }^{4}$

Burn injuries can occur in any age group at its common injury and it can be minor to major. ${ }^{5}$ there are various types of burn wounds such as second and third degree burns.

\section{Antimicrobial}

Silver sulfadiazine is a very good antibacterial agent and its approved by United States Food and Drug Administration. It has a great spectrum of activity against gram +ve and gram -ve bacteria. The silver ions which are present into the microbial DNA contribute to bactericidal activity whereas sulfadiazine interferes with bacterial metabolic processes. ${ }^{6}$ SSD also works with its lethal effect towards the microbial infection while the wound is being healed. ${ }^{7}$ So accordingly after carrying out it was concluded that nanosized SSD can interact with microbial colonies to enhance the surface area which promotes the healing of the wound. ${ }^{5}$

\section{Method Development and Validation by High Performance Liquid Chromatography}

HPTLC is a process which is suitable for Qualitative and Quantitative analysis, it has also been reported that it gives better results for separation, qualitative and quantitative analysis for compounds like herbal etc. The chromatograms which are produced are very observable of the sample and its similarities and differences can be also noticeable using the images. ${ }^{8}$

\section{Steps involved in HPTLC ${ }^{9}$}

- Sample preparation

- Selection of stationary phase

- Layer prewashing

- Selection and optimising if mobile phase

- Sample application

- Chromatogram development

- Plate labelling

- Derivatization

- Documentation

- Detection

- Quantitation

\section{MATERIALS AND METHODS}

Silver sulfadiazine was a gift sample from J P N Pharma Pvt. Ltd. Mumbai, India and Glycerol Distearate and Tween 80 was from Gattefosse, France and Hi Media
Laboratories Pvt. Ltd, Mumbai. The test microorganism used for the antimicrobial study was E. coli maintained on nutrient agar provided by Himedia Lab Ltd. Mumbai.

\section{Preformulation Study}

\section{Identification}

\section{Determination of melting point}

Melting point of silver sulfadiazine was found by using Thiele's tube apparatus. The melting point of the sample is done to check the purity of the sample.

\section{Solubility analysis}

Solubility analysis was done to find out a suitable solvent to dissolve the drug and lipid and excipients which were used for formulation preparation.

\section{FT-IR spectroscopy ${ }^{10}$}

Solid samples: The IR spectral analysis of the pure drug silver sulfadiazine was carried out. In which the physical mixture of the drug along with excipients was analysed to get a spectra which was then compared with the reference standard infrared spectrum of silver sulfadiazine.

Liquid samples: The nanosuspension containing silver sulfadiazine solid lipid nanoparticle was centrifuged at $12000 \mathrm{rpm}$ for $30 \mathrm{~min}$ and then the solid residue was collected and dried at $65^{\circ} \mathrm{C}$. Further on this residue was mixed with $\mathrm{KBr}$ and was recorded on a Thermo Scientific FT-IR Spectrometer to $4000-400 \mathrm{~cm}^{-1}$ at a resolution of $4 \mathrm{~cm}^{-1}$.

\section{Compatibility studies}

Drug lipid interaction was carried out by IR spectroscopy. IR spectra of SSD along with its lipid glycerol distearate and with lipid glycerol distearate and gelling agent carbopol were studied within range of $4000-400$ $\mathrm{cm}^{-1}$ at a resolution of $4 \mathrm{~cm}^{-1}$.

\section{Determination of $\lambda_{\max }$ of silver sulfadiazine in $0.05 \%$ ammonia solution}

The 100mg of the accurately weighed drug was transferred into a $100 \mathrm{ml}$ of volumetric flask. The drug was then dissolved using $0.05 \%$ ammonia solution and was made upto the mark to get a stock solution. From this stock solution aliquots were prepared to get a concentration of $100 \mu \mathrm{g} / \mathrm{ml}$ and this solution was then scanned between $400-200 \mathrm{~nm}$ using the blank solution as $0.05 \%$ ammonia solution. The spectrum of absorbance versus wavelength was recorded on UV-spectroscopy and analysed for absorbance maximum and the highest absorbance was noted. 


\section{Calibration curve of Silver sulfadiazine using $0.05 \%$ ammonia solution}

Silver sulfadiazine $(100 \mathrm{mg})$ was dissolved in $100 \mathrm{ml}$ of $0.05 \%$ ammonia solution in a volumetric flask. $10 \mathrm{ml}$ of above solution was diluted to $100 \mathrm{ml}$ using $0.05 \%$ ammonia solution. From this solution, aliquots of 0.5 , $1,1.5,2,2.53 \mathrm{ml}$ were transferred to $25 \mathrm{ml}$ volumetric flask and diluted upto the mark using $0.05 \%$ ammonia solution to obtain a concentration of $2-12 \mu \mathrm{g} / \mathrm{ml}$ respectively. Absorbance of each of the solution was measured at $252 \mathrm{~nm}$ in UV-spectrophotometer using $0.05 \%$ ammonia solution as blank and graph of concentration versus absorbance was plotted.

\section{Formulation, Optimisation and Preparation of Solid Lipid Nanoparticles}

Silver sulfadiazine along with glycerol di stearate and tween 80 solid lipid nanoparticles were prepared by high shear homogenisation method. Four different formulations i.e. F1, F2, F3, F4 were prepared, changing the lipid and surfactant concentrations. Required quantity of Mille $\mathrm{Q}$ water was heated at $80^{\circ} \mathrm{C}$ and then required amount quantity of surfactant was added and was continuously stirred on a magnetic stirrer. This was used as an aqueous phase. Similarly required quantity of drug (20mg) was added to lipid and was heated up to $80^{\circ} \mathrm{C}$ and stirred on magnetic stirrer. This was used as the lipidic phase. The lipid mixture was then poured drop wise to the aqueous solution at $80^{\circ} \mathrm{C}$ with constant stirring on a magnetic stirrer. The above preparation was cooled at $5^{\circ} \mathrm{C}$ and then further it was sonicated using ultra probe sonicator (VS 750). The Formulation of SSD-loaded solid lipid nanoparticles is depicted in Table 1.

\section{Evaluation of Solid Lipid Nanoparticles ${ }^{11}$}

Particle size: Particle size analysis of Silver sulfadiazine solid lipid nanoparticle is characterized by using the instrument Microtrac nanotrac A150. All the prepared Silver sulfadiazine solid lipid nanoparticle formulations were analysed for particle sizes. The mean particle size (PS) for Silver sulfadiazine solid lipid nanoparticle was measured.

Polydispersity Index (PDI): The polydispersity index is measured from dynamic light scattering instruments. The PI value is 0 if particle size are monodisperse. The narrow distribution the PI value varies between 0.10 0.10 , values of 0.5 and high specify wide particles.

Scanning Electron Microscopy: SEM plays a vital role in characterization of nanoscale and sub-micron particles. The samples of silver sulfadiazine solid lipid

\begin{tabular}{|c|c|c|c|c|}
\hline \multicolumn{5}{|c|}{ Table 1: Formulation of SSD-loaded solid lipid } \\
nanoparticles. \\
\hline Formulations & $\begin{array}{c}\text { Silver } \\
\text { sulfadiazine } \\
\text { (mg) }\end{array}$ & $\begin{array}{c}\text { Glycerol } \\
\text { distearate } \\
\text { (mg) }\end{array}$ & $\begin{array}{c}\text { Tween } \\
\mathbf{8 0} \\
(\mathbf{m g})\end{array}$ & $\begin{array}{c}\text { Milli Q } \\
\text { water } \\
\text { (ml) }\end{array}$ \\
\hline F1 & $20 \mathrm{mg}$ & 500 & 1000 & $100 \mathrm{ml}$ \\
\hline F2 & $20 \mathrm{mg}$ & 750 & 1000 & $100 \mathrm{ml}$ \\
\hline F3 & $20 \mathrm{mg}$ & 500 & 2000 & $100 \mathrm{ml}$ \\
\hline F4 & $20 \mathrm{mg}$ & 750 & 2000 & $100 \mathrm{ml}$ \\
\hline
\end{tabular}

nanosuspension was evaluated at IIT Delhi for scanning electron microscopy study.

Transmission Electron Microscopy: External Morphology of formulated solid lipid nanosuspension was determined using transmission electron microscopy.

Percentage entrapment efficiency: The dried solid lipid nanoparticle was dissolved in $50 \mathrm{ml}$ of methanol and then it was placed into ultracentrifugation for one hour at 10,000 rpm. The amount of drug which was present in the supernatant was analysed using ultra violet spectrophotometer using highest wavelength of $246 \mathrm{~nm}$ to $233 \mathrm{~nm}$. A standard calibration curve was assembled using different concentrations of silver sulfadiazine. The maximum absorbance of the supernatant of the drug loaded solid lipid nanoparticle was used to quantify silver sulfadiazine at a particular wavelength respectively,

$\% \mathrm{EE}=\frac{\text { amount of drug entrapped in nanoparticles }}{\text { theoretical amount of the drug added }} \times 100$

Determination of drug content: The gel containing $50 \mathrm{mg}$ equivalent of the drug was put to $50 \mathrm{ml}$ of volumetric flask and the make up the volume with methanol. This concentration was $1000 \mu \mathrm{g} / \mathrm{ml}$. The solution was kept aside for few minutes and then filtered and first few $\mathrm{ml}$ of the filtrate was rejected. $5 \mathrm{ml}$ of this for further diluted to $50 \mathrm{ml}$ with PBS buffer $\mathrm{pH} 7.4$ in a volumetric flask Then $10 \mu \mathrm{g} / \mathrm{ml}$ solution was prepared by further diluting $1 \mathrm{ml}$ to $10 \mathrm{ml}$ with PBS buffer $\mathrm{pH} 7.4$ in a $10 \mathrm{ml}$ volumetric flask. Absorbance was measured by UV spectroscopy at $252 \mathrm{~nm}$. The concentration of Silver sulfadiazine $(\mu \mathrm{g} / \mathrm{ml})$ was calculated by means of the standard calibration curve of Silver sulfadiazine.

Percentage yield: The solid lipid nanoparticles from all the formulations was weighed and its percentage yield was calculated 


$$
\text { Percentage yield }=\frac{\begin{array}{l}
\text { weight of solid liquid } \\
\text { nanoparticles obtained }
\end{array}}{\begin{array}{l}
\text { Weight of drug lipid and } \\
\text { excipients used }
\end{array}} \times 100
$$

In vitro drug release: Diffusion through dialysis membrane was done to evaluate the release of the drug. All the samples F1, F2, F3, F4 were evaluated in which SSD was present. Samples were placed in the dialysis bag and then they were immersed into a $50 \mathrm{ml}$ of beaker containing phosphate-buffered saline (PBS:7.4). The dialysis bags were tied with thread at both of its ends and then were suspended into the buffer. The above solution was stirred with the help of magnetic stirrer at 50rpm. Aliquots of $2 \mathrm{ml}$ dissolution medium were withdrawn at a series of various time intervals $(0.5,1,2,3,4,5,6,7,8$, $9,10,11$ and $12 \mathrm{hr}$ ) and at the same time a fresh dissolution medium was replaced. The aliquots were analysed at $252 \mathrm{~nm}$ by UV- spectrophotometer.

\section{Antibacterial study}

\section{Disk Diffusion test}

Preparation of Nutrient Agar Media: 1.05g of Nutrient agar was dissolved in $50 \mathrm{ml}$ of distilled water and was then heated so that the content dissolves and then it was autoclaved for $15 \mathrm{~min}$ at $121^{\circ} \mathrm{C}$, After autoclaving it was allowed to cool but not solidify, later this content was poured into petriplates keeping it on sterile surface until it solidifies.

Inoculation of Culture media for antimicrobial activity: A loop was dipped in E. coli culture and removed; this was carried out in aseptic area. Then agar plate was taken and the loop was touched in the middle of the plate and a spreader was used to spread the culture, later the loop was sterilised and the plate was covered

Incubation of Plates and Minimum Inhibitory Concentration (MIC) count: $10 \mathrm{~mm}$ discs were placed along with the formulation and these agar plates were then incubated at $35^{\circ} \mathrm{C}$ for $24 \mathrm{hr}$, later the zone of inhibition was measured

\section{Preparation of a Gel}

A gel containing silver sulfadiazine solid lipid nanoparticle was prepared using required amount of carbopol 934 which is a gelling agent. To the nanosuspension containing SLNs the required amount of glycerine was added which acts as a humectant. Carbopol was added to double distilled water to get hydrated for $4-5 \mathrm{hrs}$. To this the SLNs equivalent to $0.02 \%$ silver sulfadiazine was added. Triethanol amine was added to the carbopol dispersion under stirring at $1200 \mathrm{rpm}$. The gel was kept
Table 2: Formulation of a gel containing SSD-SLNs.

\begin{tabular}{|c|c|}
\hline Ingredients & Composition (\%w/w) \\
\hline Carbopol 934 & 1 \\
\hline SLN eq. to 0.02\% SSD & 1 \\
\hline Glycerin & 10 \\
\hline Triethanolamine & q.s \\
\hline Distilled water & q.S \\
\hline
\end{tabular}

overnight to remove the enclosed air. The gel was then evaluated for $\mathrm{pH}$, physical appearance, spread ability drug content, viscosity and in vitro drug release studies. The Gel formulation is depicted in Table 2.

\section{Evaluation of the Gel}

1. Physical appearance: The gel which was prepared was examined for its colour, homogeneity and presence of foreign particles.

2. $\mathrm{pH}: \mathrm{A}$ digital $\mathrm{pH}$ meter was used to check out $\mathrm{pH}$ of the gel. $1 \mathrm{~g}$ of the gel was allowed to disperse in $25 \mathrm{ml}$ of distilled water and then the $\mathrm{pH}$ was determined.

3. Viscosity: The viscosity of the gel was examined by using Brookfield rheometer. It was recorded by using the disc spindle no.52 at an optimum speed of $1 \mathrm{rpm}$.

4. Drug content: Drug content of the gel was determined by HPTLC analysis.

5. Spreadability: The spreadability of the gel was carried out by taking 2 slides of $10 \times 10 \mathrm{~cm}$ each. From which one slide is kept fixed at one position while the other slide is placed over this slide on which $5 \mathrm{~g}$ of weight is placed. The slide was allowed to stand the same position for five min. The weight which is placed is removed and the time is noted to remove the top slide. Less time taken for the separation of the two slides, gave better spreadability of the gel.it is calculated by using the formula:

$$
\mathrm{S}=\mathrm{M} \cdot \mathrm{L} / \mathrm{T}
$$

Where, $\mathrm{M}=$ weight tied to the upper slide

$\mathrm{L}=$ length of the glass slide

$\mathrm{T}=$ time taken to separate the slides

1. In vitro drug release studies: Study was performed in modified Franz diffusion cell using dialysis membrane-150. This dialysis membrane was soaked for $24 \mathrm{hr}$ in a PBS $\mathrm{pH} 7.4$. Then the membrane was clamped within the donor and the receptor cell. 1 gm of this gel was uniformly spread on the dialysis membrane. $50 \mathrm{ml}$ of PBS pH 7.4 was used as dissolution medium which was added to the receptor cell. After setting off the assembly, the assembly 
was placed on a magnetic stirrer and the solution was continuously stirred using magnetic bead, simultaneously its temperature at $37 \pm 0.5^{\circ} \mathrm{C} .2 \mathrm{ml}$ of sample was taken at a time interval of $0,0.5$, $1,2,3,4,5,6,7,8,9,10,11$ and $12 \mathrm{~h}$ of interval and at the same time it was replaced back by fresh PBS $\mathrm{pH}$ 7.4 (dilution medium). Dilutions were made of the sample and it was analysed by UV Spectrophotometer at $252 \mathrm{~nm}$ and the cumulative $\%$ drug release was calculated. The graph of $\%$ cumulative drug release versus time was plotted.

\section{HPTLC Method Development and Validation ${ }^{9}$ Selection of Wavelength detection}

Solutions of silver sulfadiazine $(10 \mu \mathrm{g} / \mathrm{ml})$ were prepared in methanol. The $\lambda_{\max }$ was determined by scanning in the range of $400-200 \mathrm{~nm}$.

The $\lambda_{\text {max }}$ of silver sulfadiazine was found to be $266 \mathrm{~nm}$. Selection and optimization of mobile phase

a) Mobile phase preparation

The mobile phase containing n-propanol: $25 \%$ ammonia in the ratio of $7: 3 \mathrm{v} / \mathrm{v}$ for preparation of elution.

b) Diluent preparation

Methanol and ammonia 25\% (1:9v/v) were used as diluent

\section{c) Standard preparation}

Silver sulfadizine containing the stock solution of $1 \mathrm{mg} / \mathrm{ml}$ was prepared in $10 \mathrm{ml}$ volumetric flask with $10 \mathrm{mg}$ of silver sulfadiazine dissolving it in 1 $\mathrm{ml}$ of $25 \%$ ammonia and then diluting to $9 \mathrm{ml}$ with methanol. Further the concentration of the stock solution was $1 \mu \mathrm{g} / \mathrm{ml}$ which was prepared and was used for further analysis.

Application of developed method to pharmaceutical dosage form (assay of gel containing Silver sulfadiazine SLNs)

Test preparation (Gel loaded with Silver sulfadiazine SLNs): $20 \mathrm{~g}$ of the gel was weighed accurately and was extracted by using $9 \mathrm{ml} \mathrm{n}$-hexane and $1 \mathrm{ml}$ ammonia. This solution was then centrifuged for $1 \mathrm{hr}$ at $12000 \mathrm{rpm}$. $1 \mathrm{ml}$ supernatant was diluted to $2 \mathrm{ml}$ with $25 \%$ ammonia for further analysis after filtering through Whatman filter paper $(0.4 \mu \mathrm{m})$ to obtain $0.2 \mathrm{mg} / \mathrm{ml}$ of sample. ${ }^{12}$

Chromatographic conditions: Chromatographic analysis was carried out on HPTLC plates which were precoated with $0.25 \mathrm{~mm}$ layer of chromatographic silica gel mixture (Silica GF 254) on aluminium sheets on which detection was carried out by TLC scanner set at a wavelength of $266 \mathrm{~nm}$.

\section{Validation Parameters ${ }^{8}$}

Linearity: To evaluate the linearity, a concentration of range of 0.2 to $1.2 \mu \mathrm{g} / \mathrm{ml}$ was used and applied to the plates from the stock solutions of $1 \mathrm{mg} / \mathrm{ml}$ by diluting with the diluent. The calibration curve was created by plotting the concentration against the mean peak area (X-axis v/s Y-axis). The correlation coefficient and the equation is shown in the Table 10 and calibration plot in Figure 15 for silver sulfadiazine.

Precision: Precision was carried out by analytical method in which multiple sampling of homogeneous samples was prepared. It is given as standard deviation or relative standard deviation. It was carried out by intra-day and inter-day variation studies. Intra-day precision was carried out in six replicates of the standard solutions at concentration level of $0.5 \mu \mathrm{g} /$ spot and was performed out twice a day. The results of repeatability were expressed as Relative Standard Deviation (\%RSD). Inter-day was carried out taking the similar method but performing it on two consecutive days.

Accuracy: Accuracy was carried out in triplicates by spiking the drug of the standard concentration of silver sulfadiazine along with the formulation (Gel loaded silver sulfadiazine SLN) at 3 different levels i.e, (75, $100,125 \%)$ and then comparing the areas which were fetched with those of the SSD SLN and the standard which were applied individually at the similar levels $(75$, $100,125 \%$ ). The results of the recovery study were depicted in Table 13

Specificity: Specificity was carried out by applying standard solution of silver sulfadiazine formulation, mobile phase and the diluents on the plates. There were peaks which were detected to determine if there was any kind of interference from the mobile phase and diluents. The results of the recovery study were depicted in Table 14 .

\section{RESULTS AND DISCUSSION Identification of pure drug FT-IR spectroscopy}

The FTIR spectrum (Figure 1) of the pure drug silver sulfadiazine and its physical mixture of drugs and glycerol di stearate was recorded by using FTIR spectrometer and it's shown in the Figure 3 respectively and this was then compared with the standard functional group frequencies of silver sulfadiazine as shown Table 3.

\section{Melting point determination}

Melting point of the sample silver sulfadiazine was determined $285^{\circ} \mathrm{C}$ which was reported in the literature, this indicates the purity of the drug sample.

\section{Solubility analysis}




\section{Table 3: Frequencies and respective functional} groups of pure Silver sulfadiazine.

\begin{tabular}{|c|c|}
\hline Frequency $\left(\mathbf{c m}^{-1}\right)$ & Functional Group \\
\hline 1016.49 & S=O stretch \\
\hline 1259.52 & C-O stretch \\
\hline 1661.07 & C=C stretch \\
\hline 3263.56 & N-H stretch \\
\hline
\end{tabular}

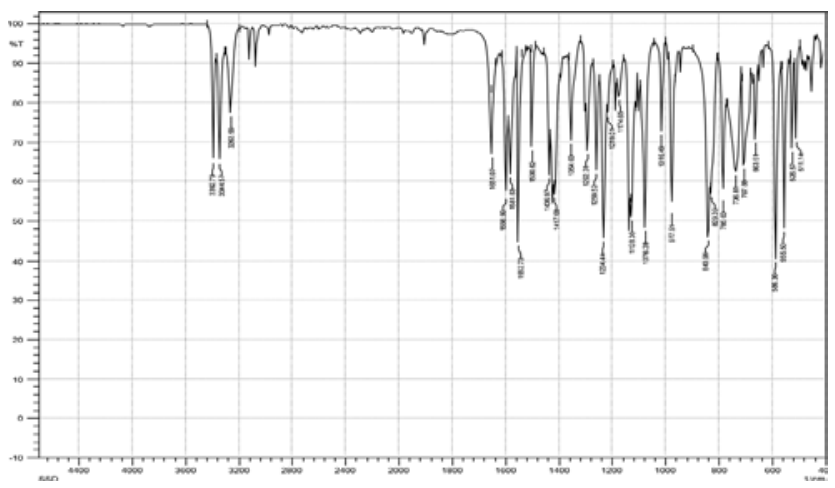

Figure 1: FTIR spectrum of Silver sulfadiazine.

Silver sulfadiazine if insoluble in distilled water, slightly soluble in acetone, practically insoluble in alcohol, chloroform, ether, freely soluble in 30\% ammonia.

\section{Compatibility studies}

\section{Compatibility by IR Spectrophotmetry}

The interaction between the drug and the lipid, the IR $\left(4000-400 \mathrm{~cm}^{-1}\right)$ spectroscopy was done. Similar peaks were noticed in the drug, lipid and carbpol mixture. The IR spectra of the drug and along with and lipid and carbopol is shown in Table 4 respectively. The spectrum of Silver sulfadiazine and the physical mixture of Silver sulfadiazine along with its excipients are listed below in Table 4. The results of the same are depicted in Figure 2-4.

\section{Determination of $\lambda_{\max }$}

The absorbance spectrum of pure drug i.e, Silver sulfadiazine was scanned between 400 to $200 \mathrm{~nm}$ on Ultra

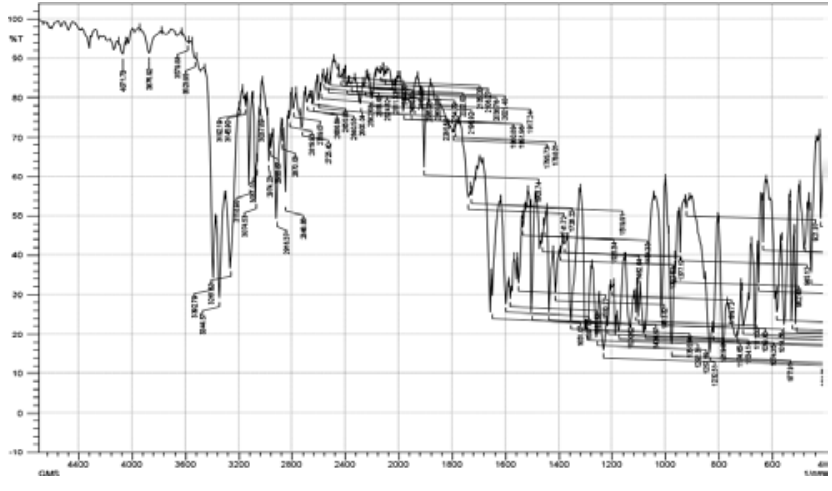

Figure 2: IR Spectrum of physical mixture of SSD and glycerol distearate.

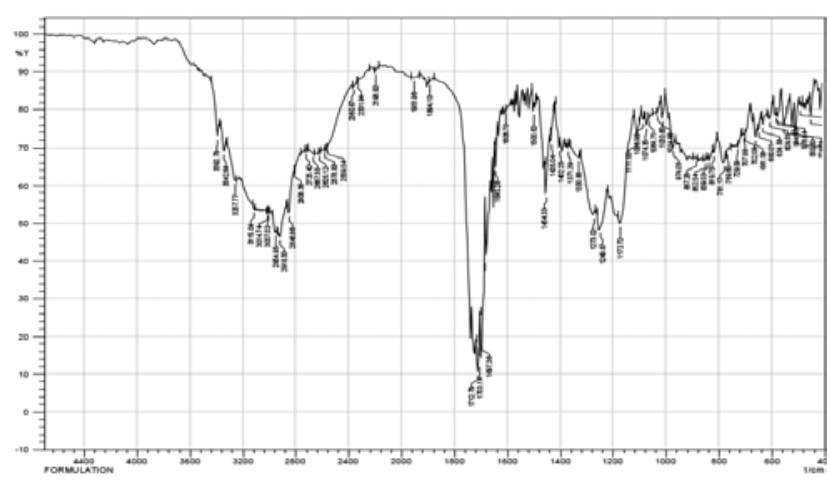

Figure 3: FTIR Spectrum of physical mixture of SSD, Carbopol and Glycerol distearate.

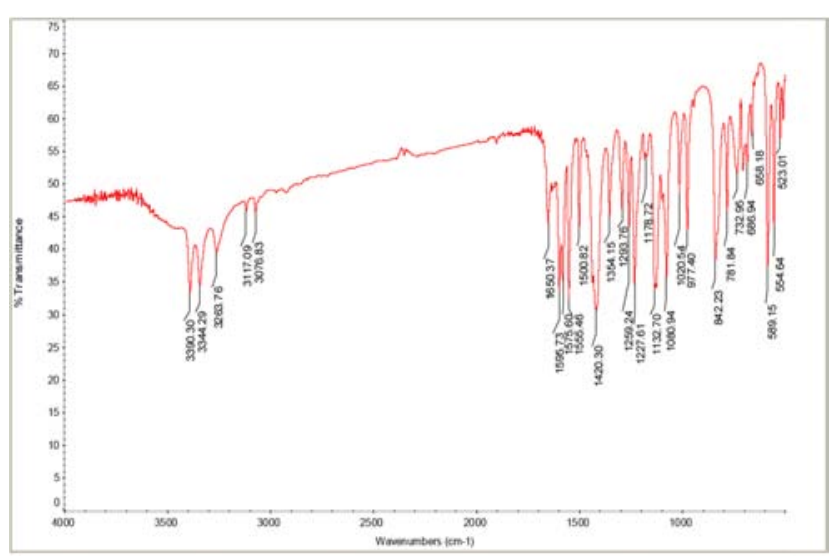

Figure 4: FTIR Spectrum of Silver sulfadiazine loaded SLNs.

\begin{tabular}{|l|c|c|c|c|c|}
\multicolumn{6}{|c|}{ Table 4: FTIR Spectral data of pure Silver sulfadiazine, the physical } \\
mixtures and the optimized formulation F4. \\
\hline $\begin{array}{c}\text { Functional } \\
\text { group }\end{array}$ & Frequency & SSD & $\begin{array}{c}\text { SSD+ Glycerol } \\
\text { distearate }\end{array}$ & $\begin{array}{c}\text { SSD + glycerol } \\
\text { distearate + } \\
\text { Carbopol }\end{array}$ & $\begin{array}{c}\text { Liquid } \\
\text { sample }\end{array}$ \\
\hline S=O stretch & $1030-1070$ & 1016.49 & 1014.56 & 1014.56 & 1020.54 \\
\hline C-O stretch & $1200-1275$ & 1259.52 & 1249.87 & 1249.87 & 1259.24 \\
\hline C=C stretch & $1661-1662$ & 1661.07 & - & 1660.71 & 1650.37 \\
\hline N-H stretch & $2500-3300$ & 3263.56 & 3257.77 & 3082.25 & 3263.56 \\
\hline
\end{tabular}




\begin{tabular}{|c|c|}
\hline $\begin{array}{c}\text { Table 5: Standard calibration curve of Silver } \\
\text { sulfadiazine. }\end{array}$ \\
\hline Concentration $(\boldsymbol{\mu g} / \mathrm{ml})$ & Absorbance \\
\hline 0 & 0 \\
\hline 2 & 0.089 \\
\hline 4 & 0.181 \\
\hline 6 & 0.293 \\
\hline 8 & 0.396 \\
\hline 10 & 0.481 \\
\hline 12 & 0.556 \\
\hline
\end{tabular}

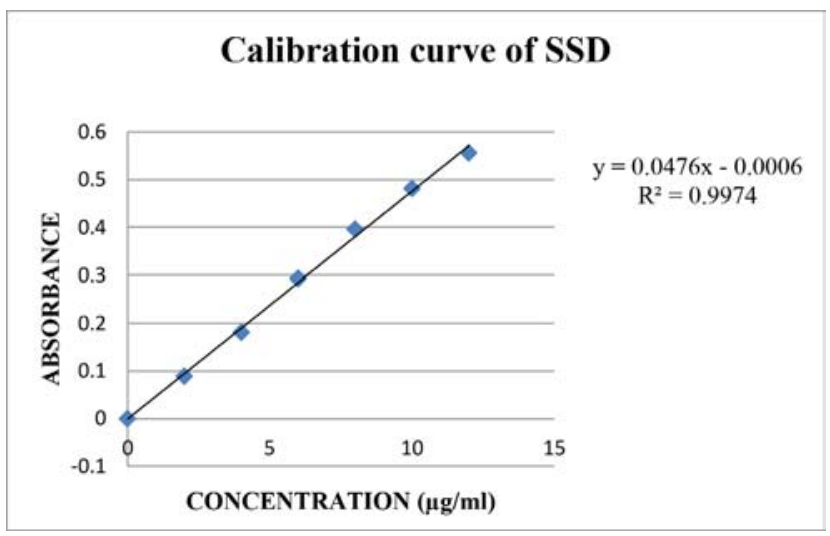

Figure 5: Calibration curve for Silver sulfadiazine.

Violet-Visible Spectrophotometer with concentration of of $100 \mu \mathrm{g} / \mathrm{ml}$ in $0.05 \%$ ammonia solution. The maximum absorption was obtained at $252 \mathrm{~nm}$.

\section{Standard calibration curve of Silver sulfadiazine}

The absorbance of silver sulfadiazine standard solution which was ranging from $2-12 \mu \mathrm{g} / \mathrm{ml}$ was measured at $252 \mathrm{~nm}$ and accordingly standard calibration curve was plotted. The curve which was plotted was Linear in the range of $2-12 \mu \mathrm{g} / \mathrm{ml}$. at $\lambda_{\max } 252 \mathrm{~nm}$. The correlation coefficient was found to be 0.997 . The calibration curve is depicted in Table 5 and Figure 5.

\section{Evaluation of Formulated SSD-SLNS ${ }^{11}$}

Particle size: Particle size and its shape is very important aspect when it comes to topical application as it has to penetrate through the skin. Particle size data of the formulations F1 - F4 were noted down in Table 5. The mean particle size of the formulated F1 to F4 formulations was different in the range from $50-200 \mathrm{~nm}$.

PDI: The polydispersity index was found by taking into consideration the mean values for the formulation which were in various ranges of 0.232 to 0.642 .

Entrapment efficiency: The values of drug entrapment efficiency of formulated formulations are listed below in the Table 5. The entrapment efficiency of the
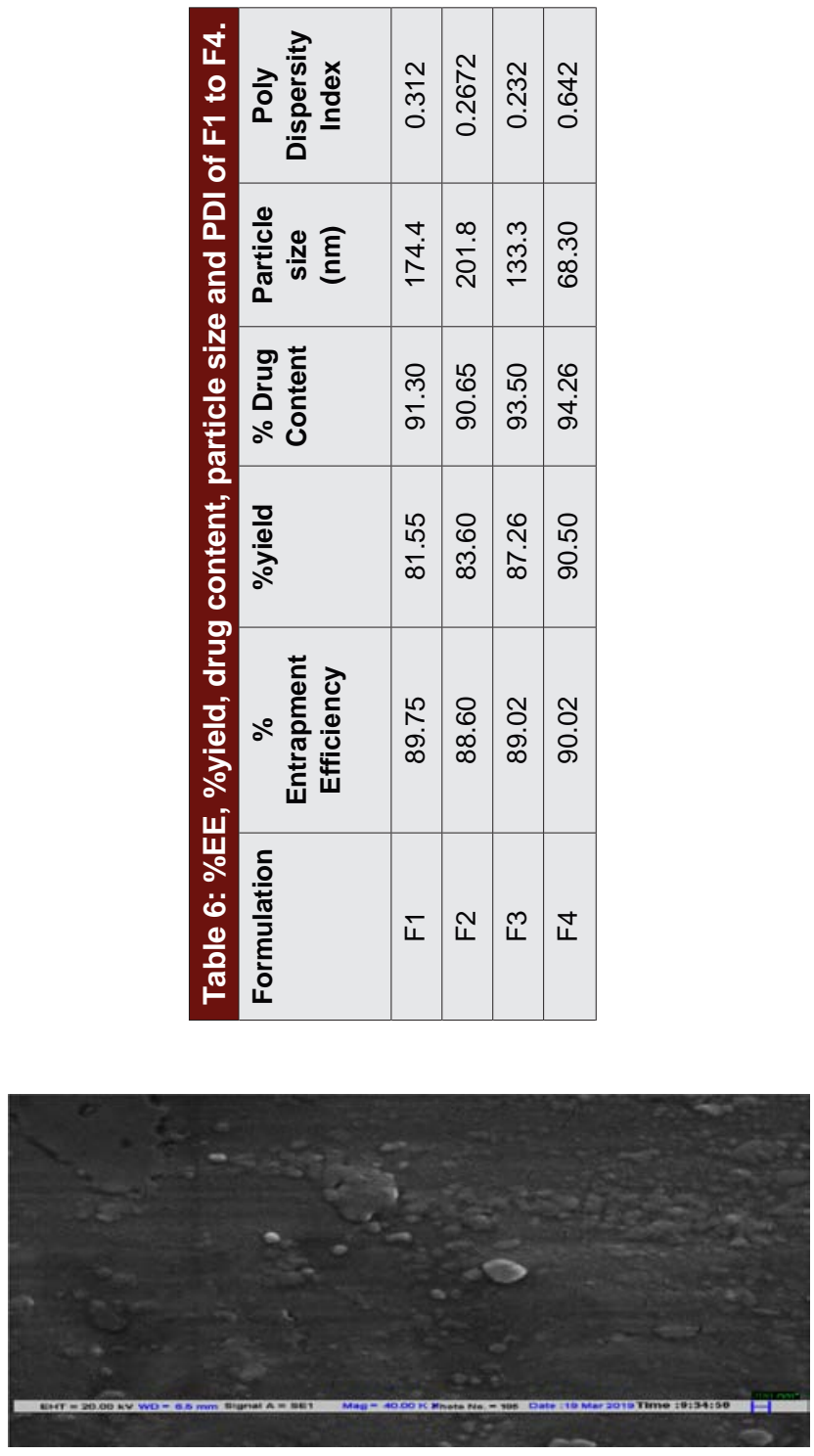

Figure 6: SEM image of optimized formulation F4.

drug is greater wen the concentration of the lipid is large.

The evaluation of the formulated SSD-SLNS is depicted in Table 6.

TEM and SEM: The TEM study suggested that the particles had a round shaped structure and were in required range of $200 \mathrm{~nm}$ as shown in Figure 7.

SEM study suggested that the particles were round in shape and there was no aggregations of particles were seen due to the presence of surfactant. As shown in Figure 6.

\section{In vitro drug release}

\section{Evaluation of the Gel}

$\mathrm{pH}$, viscosity of gel, percentage drug content and Spreadability 


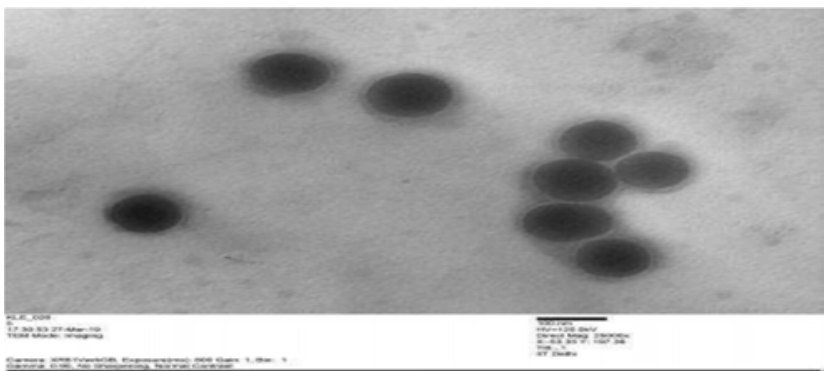

Figure 7: TEM image of optimized formulation F4.

\section{Table 7: Physical appearance, pH, viscosity and spreadability of the formulated gel.}

\begin{tabular}{|c|c|c|c|c|}
\hline Formulation & $\begin{array}{c}\text { Physical } \\
\text { Appearance }\end{array}$ & $\mathbf{p H}$ & $\begin{array}{c}\text { Viscosity } \\
\text { (cPs) }\end{array}$ & $\begin{array}{c}\text { Spreadability } \\
\text { (gm.cm/s) }\end{array}$ \\
\hline FG1 & $\begin{array}{l}\text { White in colour, } \\
\text { smooth texture }\end{array}$ & 6.63 & 11254 & 3.84 \\
\hline FG2 & $\begin{array}{l}\text { White in colour, } \\
\text { smooth texture }\end{array}$ & 6.77 & 12049 & 3.53 \\
\hline FG3 & $\begin{array}{l}\text { White in colour, } \\
\text { smooth texture }\end{array}$ & 6.75 & 10265 & 4.08 \\
\hline & $\begin{array}{l}\text { White in colour, } \\
\text { smooth texture }\end{array}$ & 6.8 & 10843 & 4.21 \\
\hline
\end{tabular}

The $\mathrm{pH}$ of all the FG4 gel formulation was found to be of 6.8 that suit the skin $\mathrm{pH}$ indicating the skin compatibility. The viscosity of the FG4 gel was found to be 10843 cps. The percentage drug content of optimized FG4 gel was found to be $98.7 \%$ which stated that drug was uniformly distributed in the gel. The spread ability of the gel was determined within 3.53 to $4.21 \mathrm{gm} . \mathrm{cm} / \mathrm{s}$. The results are depicted in Table 7, Figure 8 and 9 represents the in vitro drug release of SSD-SLNs.

\section{In vitro drug release}

\section{Antimicrobial studies}

The antimicrobial activity of the prepared gel SSD-SLNs was determined against E. coli using disk diffusion method shown in Figure 10. The mean diameter of inhibition of FG1 to FG4 are shown in the Table 8.

\section{Analytical Method Development and Validation Selection and optimization of mobile phase}

The selection of the mobile phase is very important in the development phase of chromatographic method for a specific elution, resolution, spot definition, symmetrical peak shape and $R_{f}$ reproducibility of the analyses. So the primary trials which were carried out were by using solvents like chloroform, methanol, ammonia 25\%, glacial acetic acid, distilled water, n-pro-
Table 8: Zone inhibition of the gel SSD-SLNs formulation against $E$. coli.

\begin{tabular}{|c|c|}
\hline Formulation & MIC (Zone of Inhibition) $\mathbf{~ m m}$ \\
\hline F1 & 6.4 \\
\hline F2 & 6.9 \\
\hline F3 & 7.3 \\
\hline F4 & 7.8 \\
\hline
\end{tabular}

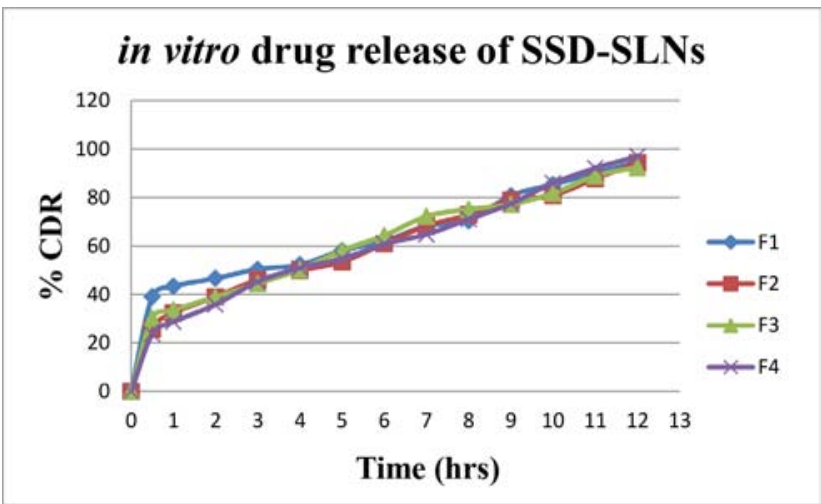

Figure 8: In vitro drug release of SSD-SLNs.

ponal. The method detected that resolution of the drug was good but the $R_{f}$ value was reproducible. After this accordingly the mobile phase was chosen as the final mobile phase was N-propanol: 25\% ammonia in the ratio of $(7: 3 \mathrm{v} / \mathrm{v})$ as this mobile phase showed better reproducibility. The results are depicted in Table 9.

Thus the optimised mobile phase used for the separation was $\mathrm{N}$-propanol: $25 \%$ ammonia in the ratio of $(7: 3 v / v)$

Track I to VI: Silver sulfadiazine

Track VII and IX: Formulation (Gel containing SSDSLNs)

Application of the developed formulation to a pharmaceutical dosage form (Assay of gel containing SSD-SLNs)

The dug content of the Gel containing silver sulfadiazine was found to be $98.7 \%$. Figure 12 represents the chromatogram of method development of Silver sulfadiazine.

\section{Validation Parameters}

Linearity: Calibration graphs were plotted using peak areas of standard drug $\mathrm{v} / \mathrm{s}$. concentration of standard drug solutions. Linear regression data revealed a good relationship over a concentration range of $0.2 \mu \mathrm{g}$ to $1.2 \mu \mathrm{g} / \mathrm{ml}$ with an equation of $\mathrm{Y}=-9.727 \times 10^{-15} x^{2}+$ 


\section{Table 9: Optimized Chromatographic condition for HPTLC analysis.}

\begin{tabular}{|c|c|}
\hline Parameters & Chromatographic Conditions \\
\hline Development chamber & CAMAG Twin Trough Chamber \\
\hline Stationary phase & $\begin{array}{c}\text { Silica gel G 60 F-254 precoated } \\
\text { on aluminum sheet }\end{array}$ \\
\hline Mobile phase & $\begin{array}{c}\text { N-propanol:25\%ammonia } \\
\text { (7:3v/v) }\end{array}$ \\
\hline Chamber saturation & 20 min \\
\hline Sample applicator & CAMAG AUTOMATIC TLC \\
SAMPLER 4
\end{tabular}

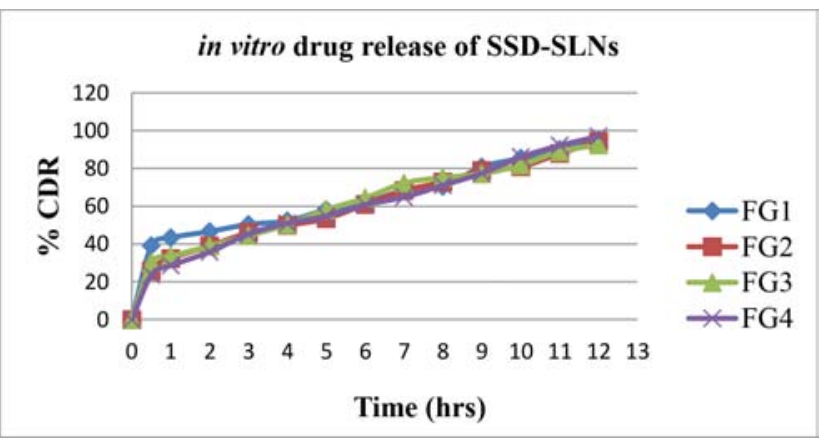

Figure 9: In vitro drug release of formulated gel containing SSD-SLNs.

\begin{tabular}{|c|c|c|c|}
\hline \multicolumn{4}{|c|}{ Table 10: Assay of Gel containing SSD-SLNs. } \\
\hline Drug & $\begin{array}{c}\text { Theoretical } \\
\text { concentration } \\
(\mu \mathrm{g} / \mathrm{spot})\end{array}$ & $\begin{array}{c}\text { Observed } \\
\text { concentration } \\
(\mu \mathrm{g} / \mathrm{spot})^{*}\end{array}$ & \% Assay \\
\hline $\begin{array}{c}\text { Silver } \\
\text { sulfadiazine }\end{array}$ & 200 & 197.4 & $98.7 \%$ \\
\hline
\end{tabular}

*average of two determinations

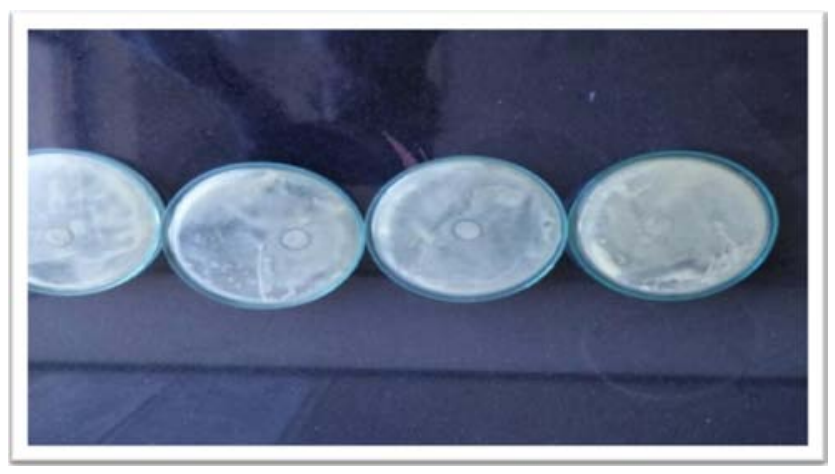

Figure 10: Antimicrobial activity of gel containing SSD-SLNs.

\section{Table 11: Calibration data for Linearity Silver} sulfadiazine by HPTLC.

\begin{tabular}{|c|c|c|}
\hline $\begin{array}{c}\text { Sr } \\
\text { no. }\end{array}$ & Concentration & Peak Area \\
\hline 1 & $0.2 \mu \mathrm{g} / \mathrm{ml}$ & 0.00616 \\
\hline 2 & $0.4 \mu \mathrm{g} / \mathrm{ml}$ & 0.01121 \\
\hline 3 & $0.6 \mu \mathrm{g} / \mathrm{ml}$ & 0.01493 \\
\hline 4 & $0.8 \mu \mathrm{g} / \mathrm{ml}$ & 0.01753 \\
\hline 5 & $1.0 \mu \mathrm{g} / \mathrm{ml}$ & 0.01958 \\
\hline \multirow{2}{*}{6} & $1.2 \mu \mathrm{g} / \mathrm{ml}$ & 0.02161 \\
\hline \multirow{2}{*}{5} & Concentration range & $0.2-1.2 \mu \mathrm{g} / \mathrm{ml}$ \\
\cline { 2 - 3 } & Correlation & 0.9988 \\
& coefficient & $Y=-9.727 \times 10^{-15} x^{2}+2.861 \times$ \\
& Equation & $10^{-8} \times+1.044 \times 10^{-3}$ \\
\cline { 2 - 3 } & &
\end{tabular}

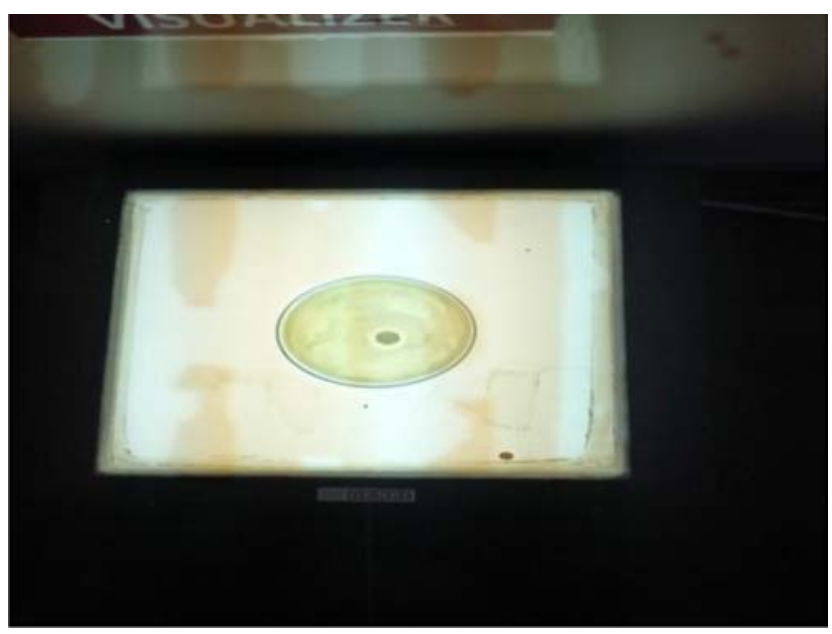

Figure 11: Optimised formulation F4.

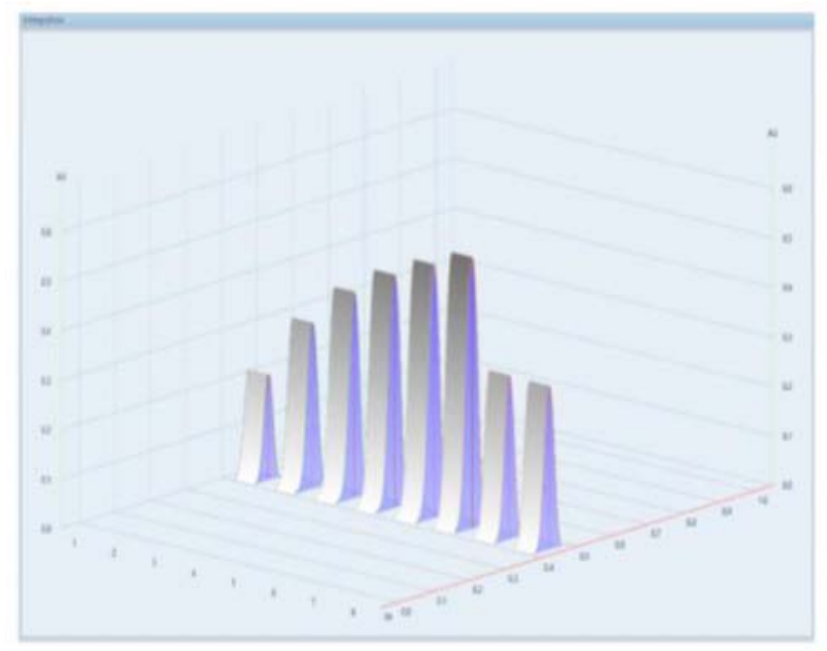

Figure 12: Chromatogram of method development of Silver sulfadiazine. 


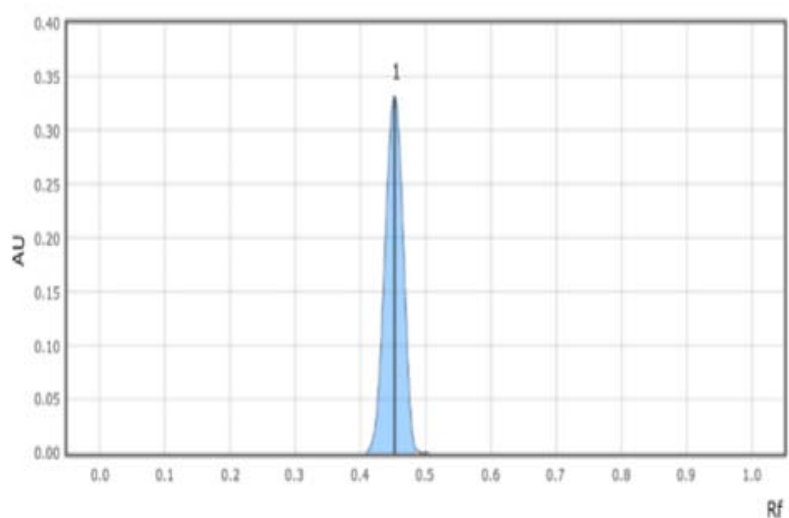

Figure 13: Chromatogram for Assay of gel containing SSD-SLNs I.

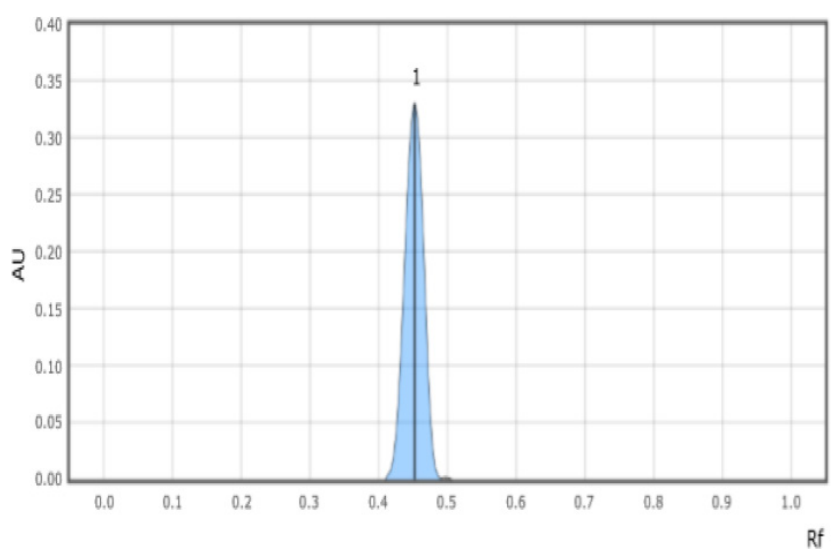

Figure 14: Chromatogram for Assay of Gel Containing SSD-SLNs II.

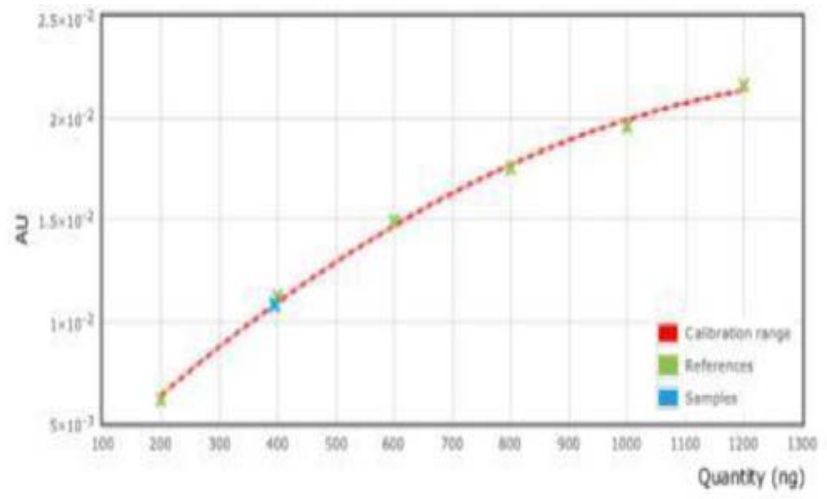

Figure 15: Calibration Curve of Silver sulfadiazine by HPTLC.

$2.861 \times 10^{-8} x+1.044 \times 10^{-3}$ and the $\mathrm{R}$ value was found to be 0.9988 .

Acceptance criteria: The correlation coefficient value $>0.995$ over the working range.

\section{Precision}

Data which was obtained from precision study are given in Table 11 for intra-day and Table 12. For Inter - day

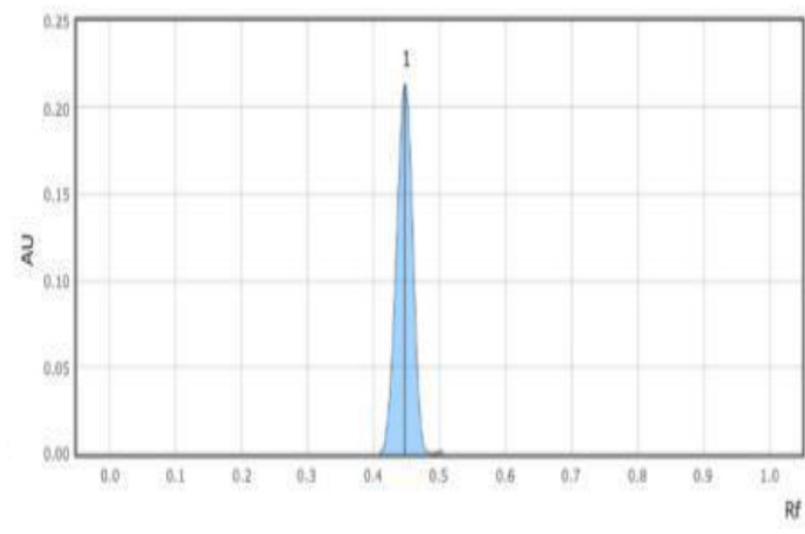

Figure 16: Chromatogram for Linearity of $0.2 \mu \mathrm{g} / \mathrm{ml}$ for Silver sulfadiazine.

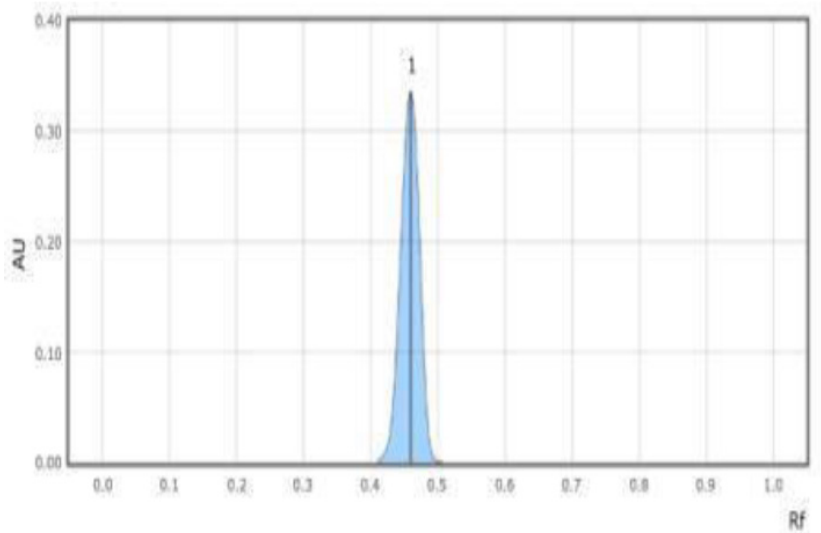

Figure 17: Chromatogram for Linearity of $0.4 \mu \mathrm{g} / \mathrm{ml}$ for Silver sulfadiazine.

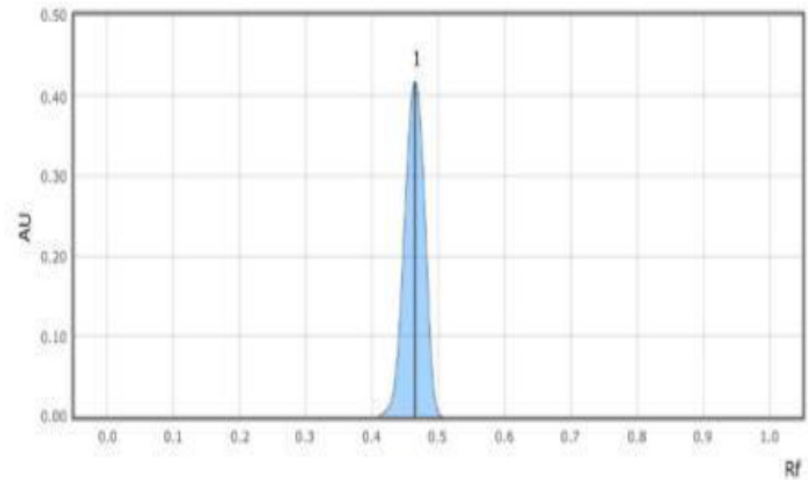

Figure 18: Chromatogram for Linearity of $0.6 \mu \mathrm{g} / \mathrm{ml}$ for Silver sulfadiazine.

precision study for Silver sulfadiazine. Intra-day precision was carried out twice a day (6 replicates). The \% RSD values for intra-day precision study was found to be 0.018 whereas Inter-day precision study was performed on two different days (replicate of 6 times). The \% RSD value for inter-day precision was 0.089 . The $\%$ RSD values for intra-day and inter-day precision 


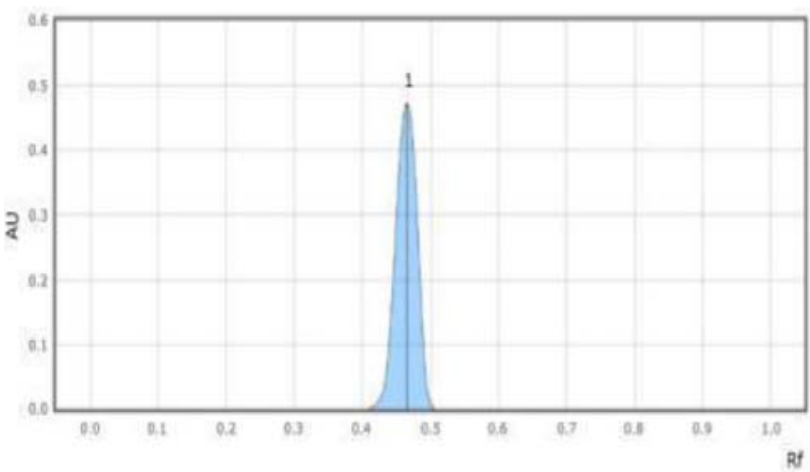

Figure 19: Chromatogram for Linearity $\mu \mathrm{g} / \mathrm{ml}$ for Silver sulfadiazine.

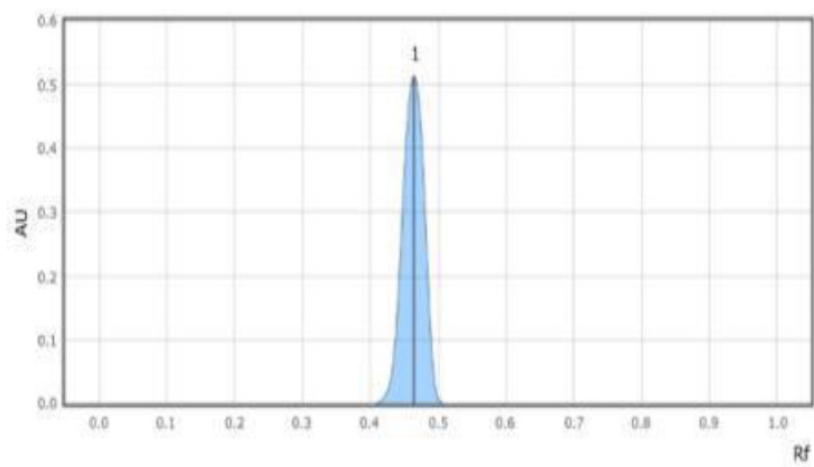

Figure 20: Chromatogram for Linearity of 0.8 of $1.0 \mu \mathrm{g} / \mathrm{ml}$ for Silver sulfadiazine.

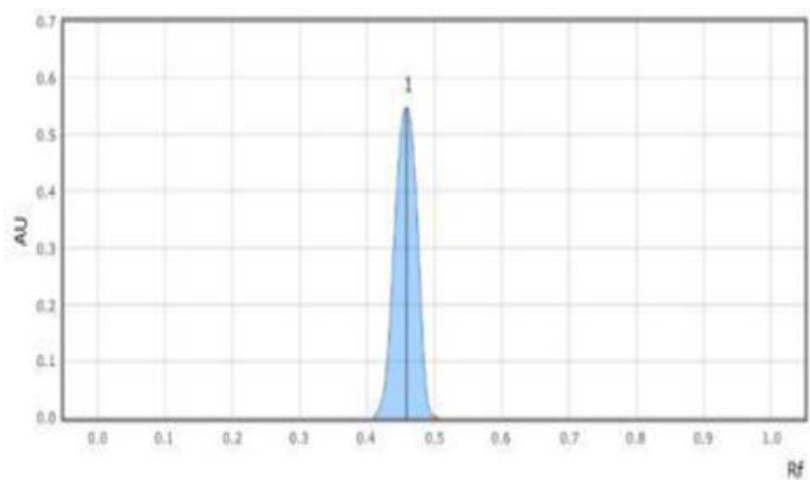

Figure 21: Chromatogram for Linearity of $1.2 \mu \mathrm{g} / \mathrm{ml}$ for Silver sulfadiazine.

were found, Silver sulfadiazine which confirmed that the method was precise. The results are depicted in Table 12 and 13. Similarly, Figure 13-21 represents the chromatogram of assay of gel containing SSD-SLNs for their linearity in different concentrations.

\section{Inter Day}

\section{Accuracy}

Accuracy of silver sulfadiazine was done in triplicates by comparing the areas of spiking the pure drug of

\begin{tabular}{|c|c|c|c|}
\hline \multicolumn{4}{|c|}{ Table 12: Intra-day Precision data for Silver } \\
sulfadiazine. \\
\hline Sr.No. & Concentration & $\begin{array}{c}\text { Mean peak area } \\
(n=6)\end{array}$ & \%RSD \\
\hline 1. & $0.5 \mu \mathrm{g} / \mathrm{ml}$ & 0.01255 & 0.011 \\
\hline 2. & $0.5 \mu \mathrm{g} / \mathrm{ml}$ & 0.01291 & 0.0119 \\
\hline & Average & 0.01273 & \\
\hline & \%RSD & 0.018 & \\
\hline
\end{tabular}

Table 13: Inter-day Precision data for Silver sulfadiazine.

\begin{tabular}{|c|c|c|c|}
\hline Sr.No. & Concentration & $\begin{array}{c}\text { Mean peak area } \\
(\boldsymbol{n}=6)\end{array}$ & \%RSD \\
\hline 1. & $0.5 \mu \mathrm{g} / \mathrm{ml}$ & 0.01291 & 0.0119 \\
\hline 2. & $0.5 \mu \mathrm{g} / \mathrm{ml}$ & 0.01469 & 0.0116 \\
\hline & Average & 0.01380 & \\
\hline & \%RSD & 0.089 & \\
\hline
\end{tabular}
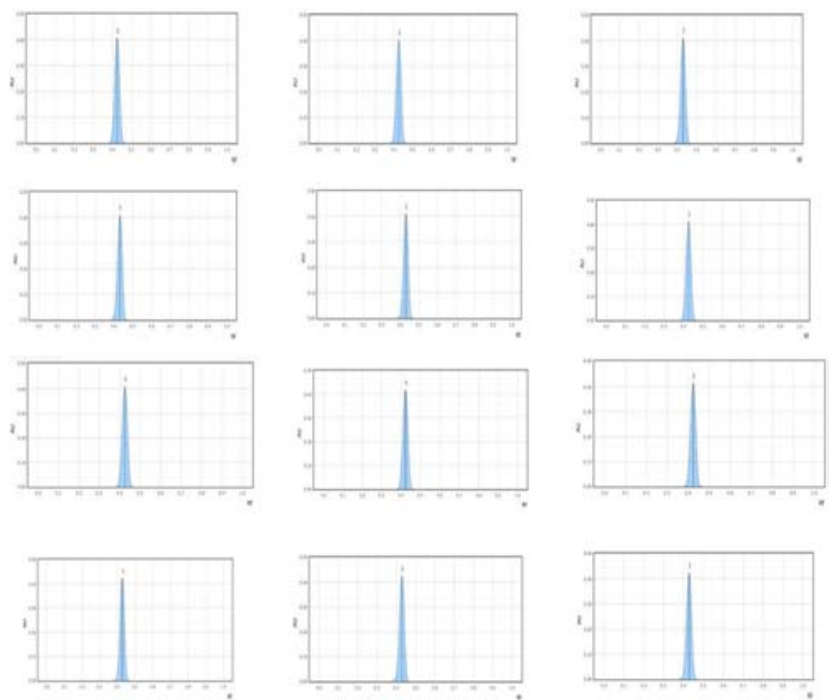

Figure 22: Chromatogram for reproducibility of $0.5 \mu \mathrm{g} / \mathrm{ml}$ of Silver sulfadiazine (Intra Day).

Silver sulfadiazine with the formulation (gel containing SSD-SLN) at 3 different levels $(75 \%, 100 \%$ and $125 \%)$ with the area obtained by spot application of the formulation and pure drugs. The $\%$ recovery of $75 \%$, $100 \%$ and $125 \%$ is found to be $87.86 \%, 85.91 \%$ and $97.21 \%$ respectively. The mean recovery for Silver sulfadiazine was $90.33 \%$. The $\%$ recovery was between the acceptance limits therefore the method was estimated as accurate.

Data for accuracy is depicted in Table 14. Figure 22 represents the chromatogram for reproducibility of $0.5 \mu \mathrm{g} /$ $\mathrm{ml}$ of Silver sulfadiazine (Intra Day). Similarly, Figure 23 and 24 represents Figure 23: Chromatogram for repro- 

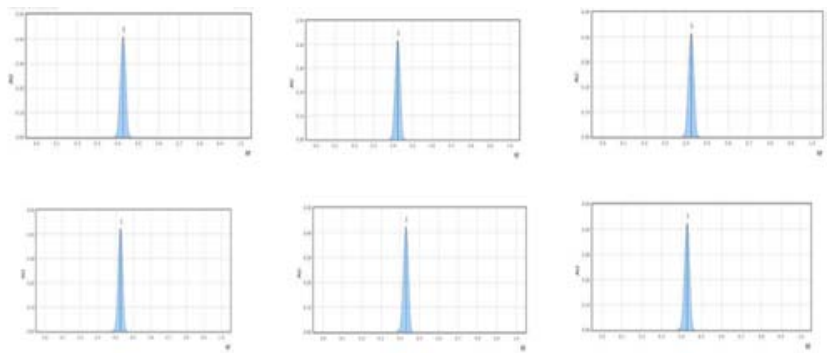

Figure 23: Chromatogram for reproducibility of $0.5 \mu \mathrm{g} / \mathrm{ml}$ of Silver sulfadiazine (Day 1).
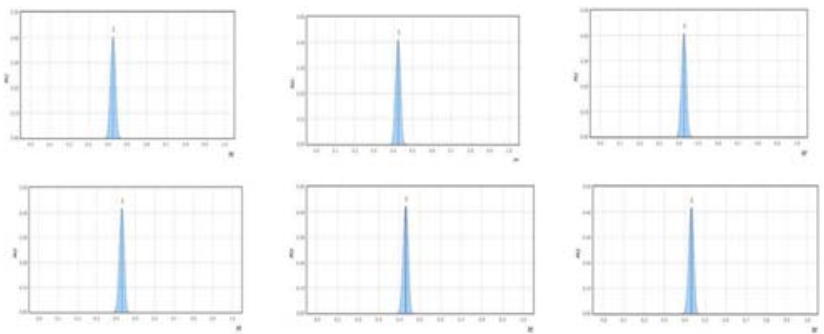

Figure 24: Chromatogram for reproducibility of $0.5 \mu \mathrm{g} / \mathrm{ml}$ of Silver sulfadiazine (Day 2).

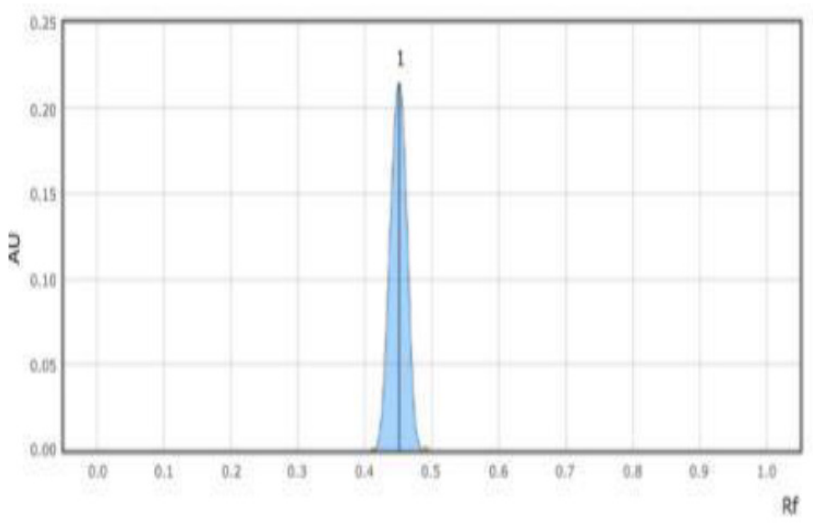

Figure 25: Chromatogram for Specificity of Silver sulfadiazine.

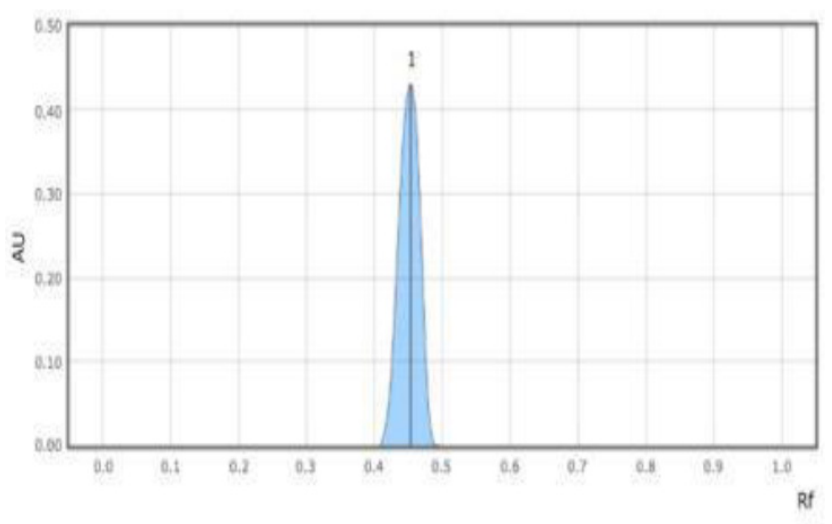

Figure 26: Chromatogram for formulation of Silver sulfadiazine.

\begin{tabular}{|c|c|c|c|}
\hline \multicolumn{4}{|c|}{ Table 14: Data for Accuracy. } \\
\hline Level & $\begin{array}{c}\text { AUC for formulation } \\
\text { and standard applied } \\
\text { on different spots* }\end{array}$ & $\begin{array}{c}\text { AUC for } \\
\text { formulation } \\
\text { and standard } \\
\text { applied on } \\
\text { same spot* }^{*}\end{array}$ & $\begin{array}{c}\% \\
\text { recovery }\end{array}$ \\
\hline $75 \%$ & 0.0086144553 & 0.0075688 & 87.86 \\
\hline $100 \%$ & 0.0103674218 & 0.0089067 & 85.91 \\
\hline $125 \%$ & 0.010773473 & 0.0104739 & 97.21 \\
\hline
\end{tabular}

Acceptance criteria: \% recovery should be within the range of $85-115 \%$. *corresponds to the average of three determents

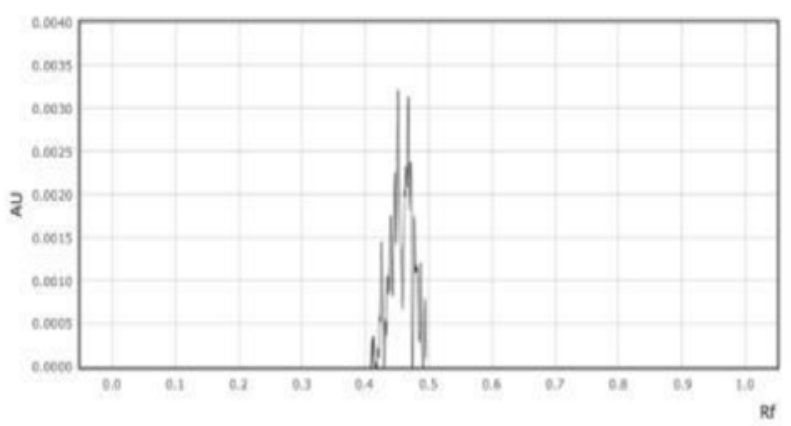

Figure 27: Chromatogram for Specificity of Mobile Phase.

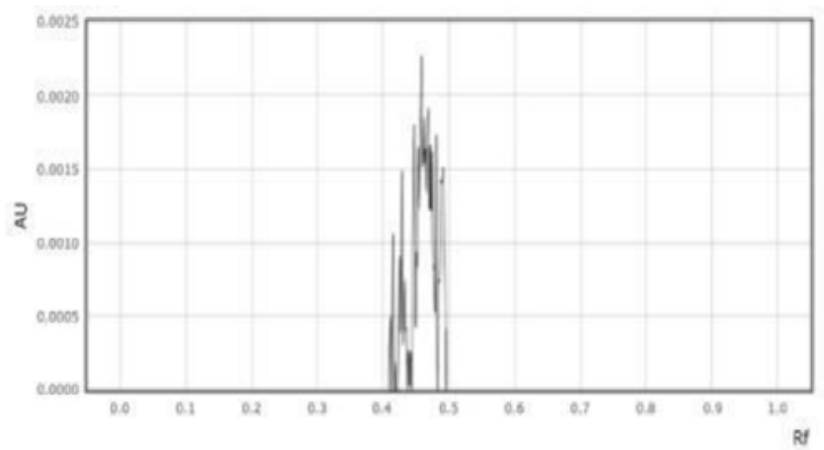

Figure 28: Chromatogram for Specificity of Diluent.

ducibility of $0.5 \mu \mathrm{g} / \mathrm{ml}$ of Silver sulfadiazine (Day 1 and 2).

\section{Specificity}

Specificity was carried out by application of standards, formulation, mobile phase and diluent.

The $\mathbf{R}_{f}$ value of Silver sulfadiazine was found to be 0.398 . The $\mathrm{R}_{f}$ value of Silver sulfadiazine was found to be 0.396 which was similar to that of the standards further the mobile phase and diluents did not show any peaks at the $\mathrm{R}_{f}$ of the standards confirming the method is specific. Figure 25 represents Chromatogram for Specificity of Silver sulfadiazine. Similrly, Figure 26, Figure 27 and Figure 28 represents the Chromatogram for formu- 
lated of Silver sulfadiazine, Specificity of Mobile Phase and Specificity of Diluent respectively.

\section{CONCLUSION}

In the present study of silver sulfadiazine solid lipid nanoparticle was successfully prepared by high shear homogenization method and it was further evaluated for its particle size, polydispersity index, shape and surface morphology, transmission electron microscopy, percentage entrapment efficiency, percentage yield, in vitro release study, method development and validation.

\section{Formulation study}

1. Melting point of silver sulfadiazine was carried out using "thiele's tube" apparatus.

2. The IR study was carried out using combinations of drug and excipients and finally was concluded that the drug and the polymer were compatible.

3. The particle size decreased with increase in the surfactant concentration. The particle size of the formulated solid lipid nanosuspension was found to be in the range of $50-200 \mathrm{~nm}$ with surfactant concentration as 1-2\%. F4 formulation showed better particle size with $68.30 \mathrm{~nm}$ at surfactant concentration of 2000 .

4. The solid lipid nanoparticles then were subjected to SEM studies and the particle size was found to spherical in shape with polydispersity index range of F1 to F4 formulation was 0.232 to 0.642 .

5. Drug entrapment efficiency was determined to be $96.98 \%$ for silver sulfadiazine for F4 formulation. It was observed that entrapment efficiency increases with increase in lipid concentration.

6. Maximum percentage yield was found to be $90.5 \%$.

7. SSD SLN gel release was dependent upon the size of the solid lipid nanoparticle and the concentration of the lipid. The lowest was F3 formulation (79.97) and highest was F4 formulation (88.64)

8. Antimicrobial study data gave good inhibition property for $\mathrm{F} 4$ formulation

\section{Analytical Study}

1. In the present study the mobile phase which was used was n-propanol: $25 \%$ ammonia in the ratio of $(7: 3 \mathrm{v} / \mathrm{v})$ and the chromatographic conditions were optimised.

2. Validation parameters i.e Linearity, Precision, Accuracy, Specificity and Assay was carried out.

3. Linearity was found over a concentration range of 0.2 to $1.2 \mu \mathrm{g} / \mathrm{ml}$ with an equation $\mathrm{Y}=-9.727 \times 10^{-15}$ $x^{2}+2.861 \times 10^{-8} x+1.044 \times 10^{-3}$ and $\mathrm{R}$ value as 0.9988 for Silver sulfadiazine.

4. Intra-day and Inter-day precision was estimated to be $<5.0 \%$ for Silver sulfadiazine which confirmed that the method was precise.

5. The mean recovery for Silver sulfadiazine was found to be $90.33 \%$. The $\%$ recovery was within the acceptance limit of $85-115 \%$ hence the method was found to be accurate.

6. The $R_{f}$ value of Silver sulfadiazine from the formulation was found to be similar from that of the standards and the mobile phase and diluent didn't show any peaks at the $R_{f}$ of the standards conforming the result was specific.

It was concluded that the developed HPTLC method is simple, quick, accurate, precise, economical and specific for the qualitative and quantitative estimation of Silver sulfadiazine with good resolution and high sensitivity.

\section{ACKNOWLEDGEMENT}

The authors would like to sincerely thank the Principal, KLE College of Pharmacy, Belagavi, J P N Pharma Pvt. Ltd, Mumbai for providing Silver sulfadiazine API as a gift sample. And would like to thank Anchrom Enterprises, Mumbai for carrying out HPTLC analysis of the formulation.

\section{CONFLICT OF INTEREST}

The authors declare no conflicts of interest.

\section{ABBREVIATIONS}

SSD: Silver sulfadiazine; +ve: Positive; -ve: Negative; \%EE: percentage Entrapment Efficiency; TEM: Transmission electron microscopy; SEM: Scanning electron microscopy; SLN: Solid Lipid Nanoparticles.

\section{REFERENCES}

1. Saxena R, Sharma P. Antibacterial and antifungal evaluation of some chalcogen bearing ligands, their transition and non-transition metal complexes. Indian J Pharma Biol Res. 2016;4(2):27-31.

2. Mukherjee S, Ray S, Thakur R. Solid lipid nanoparticles: A modern formulation approach in drug delivery system. Indian Journal of Pharmaceutical Sciences. 2009;71(4):349.

3. Kusam SR, Wook KK, Kyun $\mathrm{CH}$. Preparation and characterization of solid lipid nanoparticles loaded with doxorubicin. Eur J Pharm Sci. 2009;37(3-4):508-13. Available from: https://www.google.com/search? $\mathrm{q}=$ preparation +and +characterization+of+solid+lipid+nanoparticles+ loaded+ with+ doxorubicin\& oq=preparation+and+characterisation+of+solid+lipid+ \&aqs=chrome.1.69i57j015.22451j0j8\&sourceid=chrome\&ie=UTF-8

4. Sandri G, et al. Wound dressings based on silver sulfadiazine solid lipid nanoparticles for tissue repairing. Eur J Pharm Biopharm. 2013;84(1):84-90 http://dx.doi.org/10.1016/j.ejpb.2012.11.022 
5. Venkataraman M, Nagarsenker M. Silver Sulfadiazine Nanosystems for Burn Therapy. AAPS Pharm Sci Tech. 2012;14(1):254-64.

6. Barkat M, Harshita, Ahmad I, Ali R, Singh S, Pottoo F, et al. NanosuspensionBased Aloe vera Gel of Silver Sulfadiazine with Improved Wound Healing Activity. AAPS Pharm Sci Tech. 2017;18(8):3274-85.

7. Razavi S, Partoazar A, Takzaree N, Fasihi-Ramandi M, Bahador A, Darvishi M. Silver sulfadiazine nanoethogel for burn healing: Characterization and investigation of its in vivo effects. Nanomedicine. 2018;13(11):1319-31.

8. Chandra AD, Kant PD. High Performance Thin Layer Chromatography (HPTLC): A Modern Analytical tool for Biological Analysis. Sciencepub. net. 2010. Available from: http://www.sciencepub.net/nature/ ns0810/09_3136ns0810_58_61.pdf
9. Srivastava MM. High-Performance Thin Layer Chromatography (HPTLC). Springer-Verlag Berlin Heidelberg. 2011. doi.1007/978-3-642-14025-9_2

10. Yu SH, Mi FL, Wu YB, Peng CK, Shyu SS, Huang RN. Antibacterial activity of chitosan-alginate sponges incorporating silver sulfadiazine: Effect of ladderloop transition of interpolyelectrolyte complex and ionic crosslinking on the antibiotic release. Journal of Applied Polymer Science. 2005;98(2):538-49.

11. Souto EB, Wissing SA, Barbosa CM, Müller RH. Evaluation of the physical stability of SLN and NLC before and after incorporation into hydrogel formulations. European Journal of Pharmaceutics and Biopharmaceutics. 2004;58(1):83-90

\section{PICTORIAL ABSTRACT}

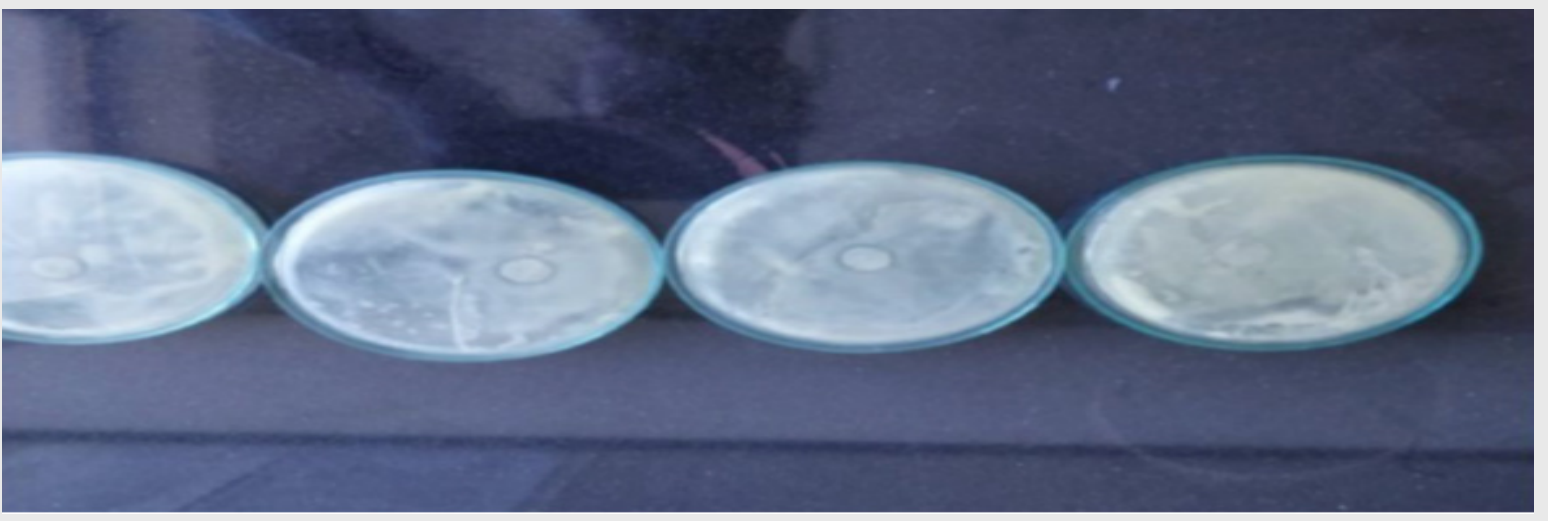

\section{SUMMARY}

- "Silver sulfadiazine" is a sulfaderivative which is basically used for second and third degree burn wounds

- "Silver sulfadiazine" "solid lipid nanoparticle" was prepared by hot homogenisation technique. These nanoparticles were then incorporated into a gel. Four batches were prepared and labelled as F1, F2, F3, F4 by varying the concentration of surfactant and lipid accordingly.

- Preformulation studies revealed that the drug "silver sulfadiazine" along with its excipients was compatible without any change or alteration in the chemical nature of the drug.

- "Silver sulfadiazine SLN" was characterized for its particle size, polydispersity index, scanning electron microscopy, transmission electron microscopy, entrapment efficiency, percentage yield, antimicrobial studies, in vitro drug release.

- Compatibility studies (FTIR) revealed that there was no chemical interference between the "SSD" and the surfactant.

- Practical yield was found to be highest in SSD - SLNs F4. Particle size of drug loaded "solid lipid nanoparticles" revealed that all the formulations are in nano range. Entrapment efficiency was increased with increasing in lipid concentration. Formulation F4 showed highest \%EE and F1 showed lowest $\%$ yield.

- "In vitro" drug release studies showed the "solid lipid nanoparticle" had good release of drug

- Antimicrobial study showed that the Formulation F4 had good inhibition property. 


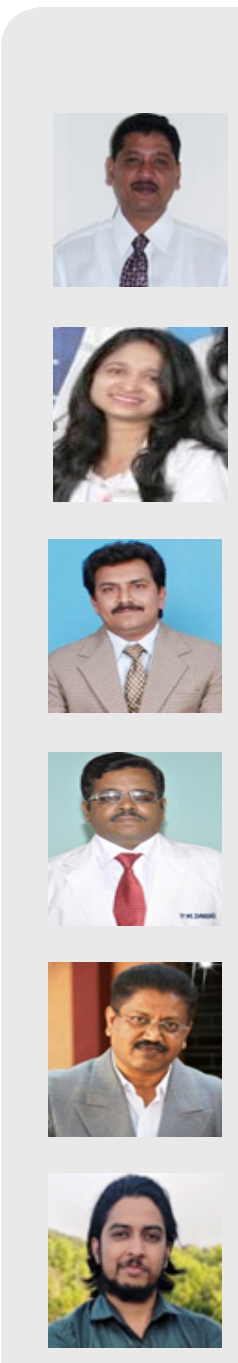

\section{About Authors}

Vinayak Shivamurthi Mastiholimath, is Professor in Department of Quality Assurance at KLE College of Pharmacy, Belagavi, KLE Academy of Higher Education and Research (KAHER), Belagavi-590010.

Coutinho Tracy Whitney Valerie, is a M. Pharm second year student in Department of Quality Assurance at KLE College of Pharmacy, Belagavi, KLE Academy of Higher Education and Research (KAHER), Belagavi-590010.

Vinod Kumar Shrishailappa Mannur, is Professor and Head in Department of Quality Assurance at KLE College of Pharmacy, Belagavi, KLE Academy of Higher Education and Research (KAHER), Belagavi-590010.

Panchaxari Mallappa Dandagi, is Professor in Department of Pharmaceutics at KLE College of Pharmacy, Belagavi, KLE Academy of Higher Education and Research (KAHER), Belagavi-590010.

Anand Panchakshari Gadad: is Professor and Head in Department of Pharmaceutics, KLE College of Pharmacy, Belagavi, KLE Academy of Higher Education and Research (KAHER), Belagavi-590010.

Pukar Khanal, has been awarded with two times gold medal for his academic performance; currently working as Ph.D Research Scholar at KLE Academy of Higher Education and Research, Belagavi. His area of interest covers gene set enrichment analysis of lead molecule modulated pathway identification, protein-protein network interaction, in silico molecular docking, protein modeling and utilizing Danio rerio as a preliminary animal model. Further, he interests to utilize regression models for the evaluation of PKPD profiles and data correlation with wet lab protocols.

Cite this article: Mastiholimath VS, Valerie CTW, Mannur VS, Dandagi PM, Gadad AP, Khanal P. Formulation and Evaluation of Solid Lipid Nanoparticle Containing Silver Sulfadiazine for Second and Third Degree Burn Wounds and its Suitable Analytical Method Development and Validation. Indian J of Pharmaceutical Education and Research. 2020;54(1):31-45.
\end{abstract}

